\section{Application and utility of alternative methods in isolation of pure cells from forensic biological mixtures in modern-day: a review}

\author{
Suneel Prajapati*, Poonam Rajmane, P Jayakrishna, Maya S \\ Nair, Priyanka Kshirsagar and Mukul Meshram
}

Department of Biology, Central Forensic Science Laboratory (CFSL), Ministry of Home Affairs, Govt. of India

\section{Summary}

Development of genetic profiles from the biological mixtures has remained challenging, although modern-day technologies may help forensic scientists to attain a reliable genetic profile in the identification of the accused.

In the case of rape, vaginal swab exhibits usually contain epithelial cells of victims and sperm cells of accused, such samples are more challenging when there is more than one contributor. In such cases, separation of distinct cells from a mixture that includes blood cells, epithelial cells and sperm cells for their single genetic profile is important.

In the last ten decades several new techniques were developed and invented for the separation of single cell from the biological mixture that includes differential lysis, laser micro-dissection, cell sorting (FACS), sieve-based filtration, (vi) micro-fluidic devices or immunomagnetic beads cell separation of fresh samples, and the magnetic activated cell sorting (MACS).

Out of them, some techniques have been commonly applied for cell separation in forensic biology. Each technique has its own limitation. Some recent studies showed, magnetic activated cell sorting (MACS), laser capture microdissection (LCM), DEPArray technology and fluorescence activated cell sorting (FACS) has proved to be effective in separation of single cell from cell mixtures.

Therefore, in this review we have evaluated these four alternative methods and their potential application in the modern-day over the others for the separation of a single cell from the mixture. In this review we also discuss the advantage of these methods and their modern-day applicability and acceptance in the forensic world.

\section{More Information}

*Address for Correspondence: Suneel Prajapati, M.Sc. Microbiology, Ph.D. Microbiology (Pers.), Department of Biology, Central Forensic Science Laboratory (CFSL), Ministry of Home Affairs, Govt. of India, Gate No. 6, Nanoli Tarafe Chakan, Pune, Maharashtra, India-410507, Tel: +917982852699; +919873976738; Email: suneel.praja@mha.gov.in; saimpj@gmail.com

Submitted: August 09, 2021

Approved: August 19, 2021

Published: August 23, 2021

How to cite this article: Prajapati S, Rajmane P, Jayakrishna $P$, Nair MS, Kshirsagar $P$, et al. Application and utility of alternative methods in isolation of pure cells from forensic biological mixtures in modern-day: a review. J Forensic Sci Res. 2021; 5: 041-047.

\section{DOI: 10.29328/journal.jfsr.1001026}

Copyright: (c 2021 Prajapati S, et al. This is an open access article distributed under the Creative Commons Attribution License, which permits unrestricted use, distribution, and reproduction in any medium, provided the original work is properly cited.

Keywords: Biological exhibits; FACS; Single cell separation; Biological mixture; Cell sorting; Genotype

Check for updates

OPEN ACCESS

\section{Introduction}

The separation of single cell or pure cells from other cell types of bio mixture in sexual assault cases has so far remained a challenge for the forensic scientists in the 21st century. Generally, they are the male sperm cells that are of forensic value in biological cell mixture specimens that are typically encountered in sexual assault cases in the back drop of the presence of excessive female cells. Various approaches were developed during the last two decades and recent advancements may help forensic scientist to process these difficult samples, like preferential lysis [1], DNA extraction from mixtures of body fluids using mild preferential lysis [2], differential lysis [3], laser micro-dissection [4,5], cell sorting [6-9], sieve-based filtration [10,11], micro-fluidic devices [12] or immunomagnetic beads cell separation of fresh samples [13]. Available methods like preferential lysis fail to separate sperm DNAs of diverse donors [14]. This usually results in multiple profiles, and can only be used for exclusion rather than identification. In the past few years, laser cut microdissection (LCM) has preferentially been used in the forensic community for isolation of single cells from mixtures [15-19]. Although, processing of gynecological samples collected post sexual assaults still remains more challenging due to the mixture of cells. While some mixtures are relatively easy to interpret, others are more complex and require precision. Such samples 
mostly contain cells of the victim and a very minute number of cells from the alleged offender [20]. In sexual assault case examination vaginal swabs and clothing or bedding items are considered the most convicting evidences [21]. Elucidation of gang rape case exhibits is a more complex process due to the multiple contributors in semen, while in the case of singlerape scenarios, DNA analysis is the simple and most candid method [21]. In a rape case, there are some certain factors that determine the complexity of a mixture. Such as, how many people contributed the DNA to the mixture? Secondly, Multi-contributors make a mixture more complex: therefore, it is more difficult to interpret. Overall, one or several people might have contributed only a tiny amount. The lower those amounts make the more complex mixture. Therefore, in the case of a complex mixture, the genetic contribution of each individual is generally not possible. Even when a mixture is composed of an identical volume of two or more different biological fluids (e.g. blood/saliva), the ratio of correspondent DNAs will still be different because of the different cellularity present in the fluids. Another factor that is impacting the mixture sample is the environmental DNA degradant; this can also increase the complexity of the mixture exhibits. This will further impair the identification process through a series of stochastic effects, such as preferential amplification, which may affect PCR [22]. In the $20^{\text {th }}$ century, different approaches have been investigated for this purpose, such as fluorescentactivated cell sorting (FACS) or laser capture microdissection (LCM), but currently none of these methods can guarantee complete separation of different types of cells present in a mixture, more over these techniques are cost effective [23]. Thus, the main concern and the center of interest in the present review article is comparison of available methods and their specific application in the modern day to separate single cells from the mixed and decay exhibits for the intact DNA extraction to develop the suitable DNA fingerprint.

\section{Materials and methods}

In this review, we have identified studies that describe or assess the isolation and genetic analysis of pure cells from biological mixtures and examine the impact of different methods on DNA yield and DNA fingerprint.

\section{Inclusion criteria}

We have selected research articles that contain estimates for at least one of the following methods: (i) differential lyses, (ii) laser micro-dissection, (iii) cell sorting (FACS), (iv) sievebased filtration, (v) micro-fluidic devices or immunomagnetic beads cell separation of fresh samples, and (vi) the magnetic activated cell sorting (MACS).

\section{Literature search}

We have searched PubMed and preprint archives for research articles published up to June 30, 2021 using the following terms: "isolation of pure cells from biological mixture", "biological mixtures for offender identification", "available methods to isolate single cells for DNA finger print from biological mixtures", "Genetic Analysis of Pure Cells from Forensic Biological Mixtures", and "methods for isolation of pure cells from biomixture". Research titles were independently reviewed by authors to eliminate studies that did not meet our inclusion criteria before the full review of abstracts and full-text of selected studies.

\section{Types of biological evidentiary items/exhibits in sexual assault case}

There is a broad range of biological evidentiary items which can be collected from the scene of crime that is referred to as biological mixture. Presence of nucleated cells in a forensic biological specimen is very crucial for forensic genetic profiling [24]. In the case of sexual assault, mixtures of secretions originating after sexual intercourse such as liquid semen, seminal stains, vaginal fluid and saliva have great value. Apart from these evidentiary items, some other exhibits could also be present such as sweats, blood, scalp hair, pubic hair, and cells of the alleged perpetrator under a victim's finger nails, or epithelial cells of the alleged victim present on the penis of the perpetrator. Such biological items are referred to as evidentiary exhibits $[25,26]$. Out of these evidentiary items, semen samples are considered the most significant exhibits to prove sexual contact and to identify an accused through DNA fingerprinting [27-30].

Collection of evidentiary exhibits : Collection of quality exhibits from the scene of crime is utmost important to develop an interpretable DNA fingerprint. Numerous kinds of evidentiary items are encountered at a crime scene such as blood, semen, epithelial cells, urine, saliva bone, and various tissues that require careful and effective collection procedure [31]. Therefore, obeying with specific processes that effectively collect cells from a variety of surfaces and preservation of collected exhibits to avoid the molecular degradation is utmost important

Evidentiary exhibits collection techniques: In forensic biology the most common collection technique is cotton swab. In this method a single swab can be taken from the suspected area. Apart from this, the wet-dry double swab technique is also frequently used for different fluids. In this method, water, buffered saline or lysis buffers can be used to moisten the swab [32]. Biological sampling kits are available commercially for swabbing. Apart from that, gauze-like materials and disposable brushes also prove handy [33]. Some other standard collection techniques like cuttings of the biological fluid exposed cloths and adhesive tape can also be used to collect the trace evidence (like pubic hair, nail clippings and nail scrapings) that may contain human DNA.

\section{Storage of biological evidentiary items}

Biological exhibits after collection, if not processed immediately, should be allowed to dry to prevent microbial 
growth. Exhibits should not be sealed immediately as excess moisture may result in microbial growth and cause degradation of evidentiary DNA. Thus, swabs and cuttings should be kept in a breathable container and storage of such evidentiary materials in cool and dry environments should be made mandatory to avoid the excess biodegradation [27].

\section{Separation of distinct cell types from the biological mixture is still challenging?}

Scientific advancementand development of new techniques help forensic scientists in offender identification even when a minute amount of biological exhibits is available. In the 21st century extremely minute biological evidentiary items can be processed in order to obtain a reliable genetic profile. Although, obtaining a genetic profile from the biomixture is still a major challenge, especially when encountered with a biological mixture consisting of biological material from two or more perpetrators. Therefore, selection of a specific and reliable method to separate single cell from mixture is utmost important to generate a valid and authentic DNA profile which makes forensic analyst enable to come to a logical conclusion.

\section{Alternative methods for the separation of pure spermatozoa from mixture for forensic DNA analysis}

There is always a scope for newly effective and specific methods to solve the mysterious forensic mixture. Although there is no effective method developed so far to distinguish sperm cells originating from different men in multi-suspect sexual assault cases. Here in this review we have converged our focus on available methods most commonly used in the separation of sperm cells from forensic mixture samples including female vaginal epithelial cells and sperm cells from multiple contributors. In the last two decades some recent and advanced methods have been developed by the scientific community for the separation of single cells based on various different approaches. This includes flow cytometry, antibodybased methods, laser-capture microdissection, DEPArray system (Menarini Silicon Biosystems) and optical tweezers. An optical tweezer is a compact, strongly focused laser beam that uses an immersion objective lens on an inverted microscope to create an optical trap [6,9,18,34-39].

\section{Magnetic-activated cell sorting (MACS)}

To develop a DNA fingerprint, there is a need for distinct cells that forensic scientists may use for the DNA extraction. Thus, selection of specific and improved cell-separation methods to obtain a single cell from a biological mixture is of utmost importance. In the last decade MACS has been most frequently used for cell separation [40]. Sperm-specific antigens are detected based on immune-magnetic beads coupled with antibodies. Major advantages associated with this technique are; it is rapid, easy to perform and economical. This technique can separate and isolate the sperm cells from the mixture of epithelial cells. The immunomagnetic cell separation binds magnetic particles to cells through an antibody interaction with surface markers of the targeted cells (Figure 1). There is a series of sperm membrane antigen found in bio mixtures of sexual assault cases and magnetic beads coated with antibodies, lectins, or enzymes that are associated with surface markers or antigens of the targeted cell group are added to a biological sample to separate the sperm cells from mixtures with epithelial cells [41,42]. Recently Xu, et al. 2016, coupled MACS and Fluorescence activated cell sorting (FACS) for the first time to isolate single sperm cells from the forensic biomixture based on the $\mathrm{ABO}$ blood type antigen antibody. This study suggests that sperms from vaginal swab can be separated by MACS using FITC-conjugated A, kinase anchor protein 3 (AKAP3) antibody. Sperm cells involving two or three donors can be separated by FACS using FITC-labeled blood group $\mathrm{ABO}$ antigen antibody. This sequential approach of combining two methods has proved to be effective for generating single donor STR profiles from the forensic mixtures. A mixture of sperm cells and female vaginal epithelial cells was prepared and separated using FITC-conjugated antiAKAP3 antibodies. The results were observed with the help of Cytofluorometric analysis by detecting the intensity of the fluorescence exhibited by the cells in the FITC channel. It was witnessed that the negative female epithelial cells showed minimal fluorescence, due to non-specific binding of the vaginal epithelial cells during purification. Flow cytometry shows that AKAP3 is sperm specific (abundantly distributed in the sperm head, neck, mid-piece and the flagellum) and that the MACS method provides highly purified sperm cells from a mixture sample. Further, STR typing analysis also confirmed the presence of only male DNA peaks from the forensic mock mixture sample. The study concludes that complete single donor STR profiles can be obtained from sperm/epithelial cell and sperm mixtures from two contributors [43]. However, according to Said, et al. (2008), subjecting a semen sample to a series of manipulations will result in substantial loss of the sample, which can be prevented by combining double density gradient centrifugation with MACS. This has yielded results which shows that the cells lost during preparation were limited to only $15 \%$ and that a positive co-relation was found between the concentration of spermatozoa and the volumes of micro-beads used [40].

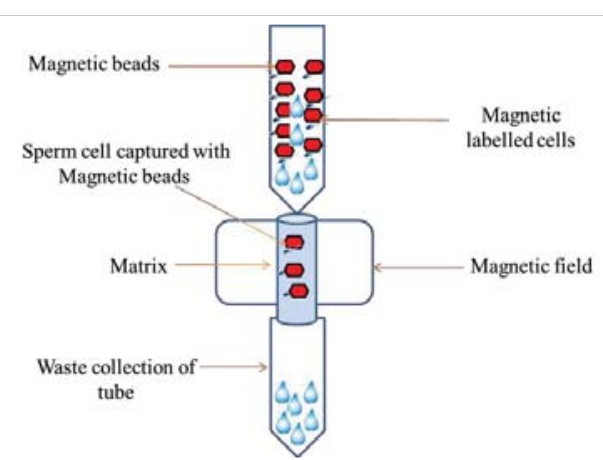

Figure 1: Magnetic activated cell sorting (MACS) separation of sperm cell from mixture by magnetic beads. 


\section{DEPArray ${ }^{\mathrm{TM}}$ technology and its application}

In DEPArray technology used to separate a cell from mixtures by a single fluorescent in a cubicle. Fluorescent tagged cells are identified under image assisted technology and moved independently. With this technique, a single cell from a cell mixture containing epithelial cells, blood cell, or sperm cell can be separated and recovered in a controlled manner. Separate kits are used to stain and isolate epithelial cells, different blood cells and sperm cells [23]. Various studies prove that the DEPArray technology is the most widely used and reliable method [44-46]. This technique is capable of detecting and isolating pure cells among the thousand contaminants, with single cell resolution. It works on the basis of immunofluorescence signals, and, therefore, the specificity and sensitivity of the antibodies used to target cell-type-specific antigens is very high based on it. This technology provides the best possible confirmation of the cell accuracy and proves cell purity [23]. The study also concluded that the DEEPArray technique is the most suitable solution to the challenges faced while handling of forensic mixtures, and for the first time it allows the complete separation of cells of two contributors present in a mixture with $100 \%$ precision and purity.

\section{Laser capture microdissection}

The laser capture microdissection (LCM) technology has proved to be the most valuable tool in separating the cells of interest from mixtures and the most widely applied in forensic science [49]. This technique is unique as it uses coupling of light microscopic with laser beam technology that allows the specific separation of interest of cell and tissue regions from mixture. LCM system has basically two key classes: 1 . Ultraviolet (UV) cutting systems [48-50]. 2. Infrared (IR) capture systems [51,52]. In Ultraviolet (UV) cutting systems, specific cells are visualized with the help of a light microscope and cells of interest are isolated through focused laser energy system. However, in the case of the Infrared capture system, cells of interest are transferred by a thermoplastic polymer through development of a polymer-cell composite [47]. Now a day's Laser micro-dissection and sample collection method is highly advanced with an automated system and accompanied with contaminant-free micro tubes. This technique is highly sophisticated and needs expertise to perform capture. Laser capture micro-dissection through the H\&E staining proved to be effective in order to isolate male genetic profiles from recovered sperm cells [53]. This technique is implemented widely in sexual assault crimes encountered in forensics. However, it can also be used in other forensic applications such as in separation of a single hair follicle which eventually provides a robust and more efficient DNA extraction that may help in developing good quality STR amplification and DNA typing. This technique can also be used for isolation of blood cells from different cell mixtures and blood cells from saliva mixture [54-56].

\section{Fluorescence-activated cell sorting}

Fluorescence-activated cell sorting (FACS) is extensively used in the medical setting for diagnostic and research purposes. Despite its usefulness, FACS has rarely been used for the analysis of forensic samples; however, several efforts have been made to make FACS a mainstream method. FACS was introduced in the late 1990 to separate the sperm cells from vaginal epithelial cells as a superior method [7]. This technique is based on the principal of Forward Scatter (FSC) and Side Scatter (SSC). It works on cell size and cell granularity (Figure 2). It relies on differences in the cell size, shape, surface phenotype, cytoplasm and DNA content. It has been reported that flow cytometry has improved sensitivity relative to preferential lysis in identifying male DNA in a mixture. In this method the cells of interest are labeled with fluorescently tagged antibodies so that positive, dyed cells can be isolated from negative ones in a flow cytometer [7]. Although, very limited no. of study has been performed so far by using FACS (fluorescent-activated cell sorting) to separate distinct cells from forensic mixtures, including sperm cells and epithelial cells mixtures [7]. Recently, a group of Australian researchers utilized FACS for the separation of cellular mixtures before DNA extraction [9]. 14 different ratios of blood and saliva mixtures were analyzed by FACS to identify saliva-based epithelial cells; anti-CD227 was used to target the specific cells, whereas blood-derived leukocytes were targeted with an anti-CD45 probe. This work not only demonstrated the usefulness of FACS for separating fresh blood and saliva mixtures but also proved its usefulness in improving the number of detectable alleles from targeted cell types during subsequent DNA extraction and analysis [9]. Apart from this, another study showed the wide application by means of HLA antibody probes coupled to FACS [34]. The study showed for the first time that this method can be applied for isolation of single donor cells from mixed sperm cells involving plural contributors based on their ABO blood types [43]. Despite its usefulness, FACS has rarely

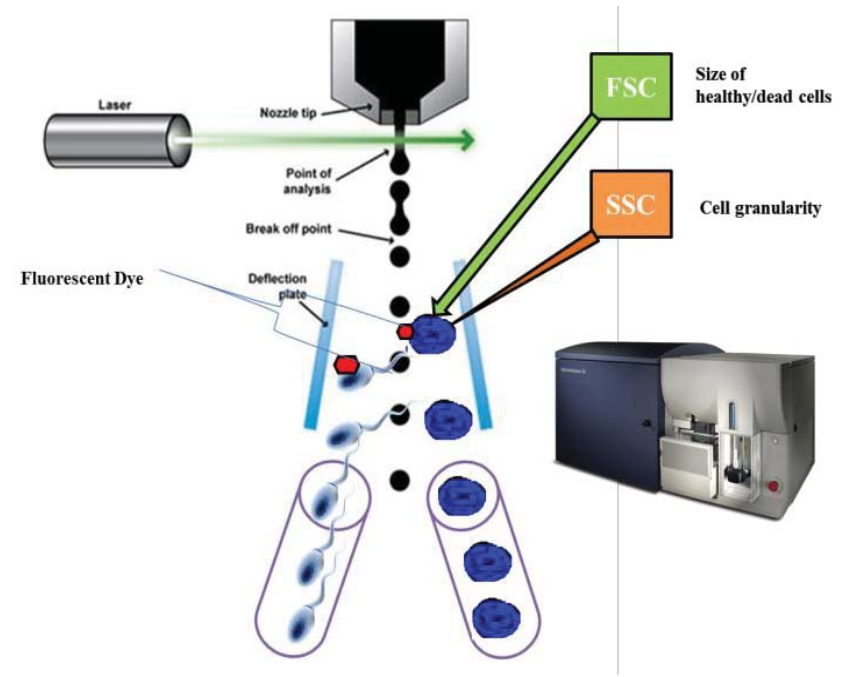

Figure 2: A systemic representation of fluorescent tagged sperm cells separation from biological mixture by fluorescent activated cell sorter. 
been used for the analysis of forensic samples; however, several efforts have been made to make FACS a mainstream method. Some of the earliest applications of FACS analysis in forensic science included its use to separate mixed sperm and vaginal epithelial cell populations. Also, to begin with a costly technique at the time, this preliminary attempt only utilized markers that were specific to sperm cells, thereby limiting the validity of this method. As cell sorting machines have undergone considerable technological advancements over the past several decades, cell sorting has become more sensitive to a point where single-cells can be isolated and identified. The value of this concept has been proven; however, more research is essential before FACS could be applied to actual forensic samples on a big scale.

\section{Advantage of these methods and its modern day applications}

Despite the recent methodological advancement, there is a dire need to combine MACS with other sperm preparation techniques including double density gradient centrifugation or a one-step sperm wash. According to Said, et al, combining the MACS with double density centrifugation has resulted in spermatozoa with the highest quality of vitality, motility and morphology [40]. In future the development of magnetic cell separation techniques offers a wide range of improved sperm cell sorting results with a technique named magneto phoretic mobility, which allows the magnetically tagged cell to distinguish from the unlabeled ones in a cell suspension $[57,58]$. The success of MACS technique will greatly depend on the implementation of efficient and specific immune-labeling strategies. The newly developed DEPArray Forensic Sample Prep Kit has proved ground breaking as it combines digital sorting and immune fluorescence markers with image-based selection to provide single cell isolation with highest precision [23]. In addition, LCM has proven to be a valuable tool in the efficient separation of pure cells from heterogeneous sample in the most difficult of forensic evidence. It can be put to use for a wide range of forensic applications, especially where a minute trace of evidence has been encountered. LCM has been used for other forensic evidence such as isolation of biological samples from the debris in the soil, on an adhesive tape that is most likely to contain skin flakes or dandruff, etc. There are a few disadvantages to this technique such as staining and DNA extraction protocols which can be overcome with new applications that will be developed in the future [18].

Furthermore, combined use of MACS and FACS has proven to be effective in sexual assault cases for generating single donor STR profiles from the mixtures containing female vaginal epithelial cells and sperm cells originating from multiple men. However, in order to aid forensic investigation, this technique needs to be further optimized given the potential drawbacks. This technique relies mainly on cell count and an intact cell structure, making it highly suitable for detection of fresh samples. It has been observed that an ABO antibody based cell mixture separation protocol by FACS was able to identify secretor to that of non-secretor, the ratio of which is $4: 1$ in the general population. The problem arises when the sample has less mixture ratio and more contributors. It is advisable to use this technique in combination with next-gen DNA sequencing and type specific antibodies [43].

\section{Conclusion}

This review is focused on four alternative methods which have essentially proved to be the most useful in separating the cells from the biological mixtures. With DNA mixtures, the results can be ambiguous and difficult to understand, even for the experts. Although no effective method has been developed so far to discriminate sperm cells originating from different men in multi-suspect sexual assault cases. In this article we state that DEPArray technology, MACS, LCM and FACS provide an answer to the need for a technology for efficient separation of cells from difficult forensic samples and for rapid isolation of pure cell populations from heterogeneous samples. This technique seems to be promising and can be applied to a wide range of cases in forensics. This review summarizes all the published forensic applications of DEPArray technology, MACS, LCM and FACS. However, the published data suggest that the DEPArray and automated LCM have an edge over the other alternative methods. Nevertheless, it is certain that new coupled applications of MACS and FACS can be useful in the future to separate the distinct cells from a mixture, and it may be an acceptable method in forensic biology. The use of these alternative methods should be implemented in every forensic case where minute traces need to be separated from a mixture.

Ethical standards: This article does not contain any studies with human participants or animals performed by the authors.

\section{References}

1. Gill P, Jeffreys AJ, Werrett DJ. Forensic application of DNA 'fingerprints'. Nature. 1985; 318: 577-579.

PubMed: https://pubmed.ncbi.nlm.nih.gov/3840867/

2. Wiegand $P$, Schurenkamp $M$, Schutte $U$. DNA extraction from mixtures of body fluid using mild preferential lysis. Int J Legal Med. 1992; 104: 359-360.

PubMed: https://pubmed.ncbi.nlm.nih.gov/1515365/

3. Yoshida K, Sekiguchi K, Mizuno N, Kasai K, Sakai I, et al, The modified method of two-step differential extraction of sperm and vaginal epithelial cell DNA from vaginal fluid mixed with semen. Forensic Sci Int. 1995; 72: 25-33.

PubMed: https://pubmed.ncbi.nlm.nih.gov/7705732/

4. Anslinger K, Bayer B, Mack B, Eisenmenger W. Sex-specific fluorescent labelling of cells for laser microdissection and DNA profiling. Int $\mathrm{J}$ Legal Med. 2007; 121: 54-56.

PubMed: https://pubmed.ncbi.nlm.nih.gov/16552569/

5. Sanders CT, Sanchez N, Ballantyne J, Peterson DA. Laser microdissection separation of pure spermatozoa from epithelial cells for short tandem repeat analysis. J Forensic Sci. 2006; 51: 748-757. PubMed: https://pubmed.ncbi.nlm.nih.gov/16882215/ 
6. Schoell WM, Klintschar M, Mirhashemi R, Pertl B. Separation of sperm and vaginal cells with flow cytometry for DNA typing after sexual assault. Obstet Gynecol. 1999; 94: 623-627.

PubMed: https://pubmed.ncbi.nlm.nih.gov/10511370/

7. Schoell WM, Klintschar M, Mirhashemi R, Strunk D, Giuliani A, et al. Separation of sperm and vaginal cells based on ploidy, MHC class I, CD45-, and cytokeratin expression for enhancement of DNA typing after sexual assault. Cytometry. 1999; 36: 319-323.

PubMed: https://pubmed.ncbi.nlm.nih.gov/10404147/

8. Di Nunno N, Melato M, Vimercati A, Di Nunno C, Costantinides F, et al. DNA identification of sperm cells collected and sorted by flow cytometry. Am J Forensic Med Pathol. 2003; 24: 254-270.

PubMed: https://pubmed.ncbi.nlm.nih.gov/12960662/

9. Verdon TJ, Mitchell RJ, Chen W, Xiao K, van Oorschot RA. FACS separation of non-compromised forensically relevant biological mixtures. Forensic Sci Int Genet. 2015; 14: 194-200.

10. Chen J, Kobilinsky L, Wolosin D, Shaler R, Baum H. A physical method for separating spermatozoa from epithelial cells in sexual assault evidence. J Forensic Sci. 1998; 43: 114-118.

PubMed: https://pubmed.ncbi.nlm.nih.gov/9456531/

11. Garvin AM. Filtration based DNA preparation for sexual assault cases. J Forensic Sci. 2003; 48: 1084-1087.

PubMed: https://pubmed.ncbi.nlm.nih.gov/14535671/

12. Horsman KM, Barker SL, Ferrance JP, Forrest KA, Koen KA, et al. Separation of sperm and epithelial cells in a microfabricated device: potential application to forensic analysis of sexual assault evidence. Anal Chem. 2005; 77: 742-749.

PubMed: https://pubmed.ncbi.nlm.nih.gov/15679339/

13. Li XB, Wang QS, Feng Y, Ning SH, Miao YY, et al. Magnetic bead based separation of sperm from buccal epithelial cells using a monoclonal antibody against MOSPD3. Int J Legal Med. 2014; 128: 905-911. PubMed: https://pubmed.ncbi.nlm.nih.gov/24590379/

14. Feng L, Xu C, Zeng $\mathrm{X}$, Zhang $\mathrm{H}$, Yang $\mathrm{F}$, et al. Y-chromosomal haplotyping of single sperm cells isolated from semen mixtures - a successful identification of three perpetrators in a multisuspect sexual assault case. Croat Med J. 2014; 55: 537-415

PubMed: https://pubmed.ncbi.nlm.nih.gov/25358887/

15. Budimlija ZM, Popiolek D, Fogt F, Prinz M. Forensic applications of laser capture microdissection: use in DNA-based parentage testing and platform validation. Croat Med J. 2005; 46: 549-555.

PubMed: https://pubmed.ncbi.nlm.nih.gov/16100757/

16. D i Martino D, Staiti N, Simone A, Todaro P. Laser microdissection and DNA typing of cells from single hair follicles. Forensic Sci Int. 2004; 146: S155-157.

PubMed: https://pubmed.ncbi.nlm.nih.gov/15639565/

17. E lliott K, Lambert C, Burroughes TR, Gill P. Use of laser microdissection greatly improves the recovery of DNA from sperm on microscope slides. Forensic Sci Int. 2003; 137: 28-36.

PubMed: https://pubmed.ncbi.nlm.nih.gov/14550610/

18. Vandewoestyne M, Deforce D. Laser capture microdissection in forensic research: a review. Int J Legal Med. 2010; 124: 513-521. PubMed: https://www.ncbi.nlm.nih.gov/pmc/articles/PMC2952761/

19. Vandewoestyne M, Van Hoofstat D, Van Nieuwerburgh F, Deforce D. Suspension fluorescence in situ hybridization (S-FISH) combined with automatic detection and laser microdissection for STR profiling of male cells in male/female mixtures. Int $\mathrm{J}$ Legal Med. 2009; 123: 441-447. PubMed: https://pubmed.ncbi.nlm.nih.gov/19319556/

20. Castella V, Dimo-Simonin C, Mangin P. Forensic evaluation of the QIAshredder/QIAamp DNA extraction procedure Foren Sci Int. 2006; 156: 70-73.

PubMed: https://pubmed.ncbi.nlm.nih.gov/16326058/

21. Seah LH, Wee BH. Separation patterns of sperm mixtures: The majorminor impact. For Sci Inte: Genetics Supplement Series. 2015; 5 : e582-e583.
22. Gill P, Haned H, Bleka O, Hansson O, Dorum G, et al. Genotyping and interpretation of STR-DNA: Lowtemplate,mixtures and database matches-Twenty years of research and development. Forensic Sci Int Genet. 2015; 18: 100-117.

PubMed: https://pubmed.ncbi.nlm.nih.gov/25866376/

23. Fontana F, Rapone C, Bregola G, Aversa R, deMeo A, et al. Isolation and genetic analysis of pure cells from forensic biological mixtures: The precision of a digital approach. Forensic Sci Int Genet. 2017;29:225-241. PubMed: https://pubmed.ncbi.nlm.nih.gov/28511094/

24. Kuperus WR, Hummel KH, Roney JM. Crime scene links through DNA evidence: the practical experience from Saskatchewan casework. Can Soc Forensic Sci J 2003; 36: 19-28.

25. Farmen RKB, Haukeli I, Ruoff P, Froyland ES. Assessing the presence of female DNA on post-coital penile swabs: relevance to the investigation of sexual assault. J Forensic Leg Med. 2012; 19: 386-389. PubMed: https://pubmed.ncbi.nlm.nih.gov/22920760/

26. Sweet D, Lorente M, Lorente JA, Valenzuela A, Villanueva E. An improved method to recover saliva from human skin: the double swab technique. J Forensic Sci. 1997; 42: 320-322.

PubMed: https://pubmed.ncbi.nlm.nih.gov/9068193/

27. Lee HC, Ladd C. Preservation and collection of biological evidence. Croatian Med J. 2001; 42: 225-228.

PubMed: https://pubmed.ncbi.nlm.nih.gov/11387627/

28. Khaldi N, Miras A, Botti K, Benali L, Gromb S. Evaluation of three rapid detection methods for the forensic identification of seminal fluid in rape cases. J Forensic Sci. 2004; 49: 749-753.

PubMed: https://pubmed.ncbi.nlm.nih.gov/15317189/

29. Bozzo WR, Colussi AG, Ortiz MI, Lojo MM. DNA recovery from different evidences in 300 cases of sexual assault. Forensic Sci Inter Geneti Supple Seri. 2009; 2: 141-142.

30. Johnson D, Peterson J, Sommers I, Baskin D. Use of forensic science in investigating crimes of sexual violence: contrasting its theoretical potential with empirical realities. Violence Against Women. 2012; 18: 193-222. PubMed: https://pubmed.ncbi.nlm.nih.gov/22433228/

31. Lee HC, Ladd C, Scherczinger CA, Bourke MT. Forensic applications of DNA typing: part 2: collection and preservation of DNA evidence. Am J Forensic Med Pathol. 1998;19:10-18.

PubMed: https://pubmed.ncbi.nlm.nih.gov/9539385/

32. Leema P. Evaluation and methodology for the isolation and analysis of LCN-DNA before and after dactyloscopic enhancement of fingerprints. Int Congress Ser. 2006; 1288: 583-585.

33. Lauk C, Schaff J. A New Approach for the Extraction of DNA from Postage Stamps. Forensic Science Communications. 2007; 9.

34. Dean L, Kwon YJ, Philpott MK, Stanciu CE, Seashols-Williams SJ, et al. Separation of uncompromised whole blood mixtures for single source STR profiling using fluorescently-labeled human leukocyte antigen (HLA) probes and fluorescence activated cell sorting (FACS). Forensic Sci Int Genet. 2015; 17.

PubMed: https://pubmed.ncbi.nlm.nih.gov/25796046/

35. Zhao XC, Wang L, Sun J, Jiang BW, Zhang EL, et al. Isolating Sperm from Cell Mixtures Using Magnetic Beads Coupled with an Anti-PH-20 Antibody for Forensic DNA Analysis. PLoS One. 2016; 11: e0159401. PubMed: https://pubmed.ncbi.nlm.nih.gov/27442128/

36. Xu Y, Xie J, Chen R, Cao Y, Ping Y, et al. Fluorescence- and magneticactivated cell sorting strategies to separate spermatozoa involving plural contributors from biological mixtures for human identification. Sci Rep. 2016; 6: 36515.

PubMed: https://pubmed.ncbi.nlm.nih.gov/27857155/

37. Murray C, McAlister C, ElliottK. Identification and isolation of male cells using fluorescence in situ hybridisation and laser microdissection, for use in the investigation of sexual assault. Forensic Sci Int Genet. 2007; 1: 247-252. PubMed: https://pubmed.ncbi.nlm.nih.gov/19083769/

38. Williamson VR, Laris TM, Romano R, Marciano MA. Enhanced DNA 
mixture deconvolution of sexual offense samples using the DEPArrayTM system. Forensic Sci Int Genet. 2018; 34: 265-276.

PubMed: https://pubmed.ncbi.nlm.nih.gov/29602061/

39. Ashkin A, Dziedzic JM, Bjorkholm JE, Chu S. Observation of a single-beam gradient force optical trap for dielectric particles. Opt Lett. 1986; 11: 288. PubMed: https://pubmed.ncbi.nlm.nih.gov/19730608/

40. Said TM, Agarwal A, Zborowski M, Grunewald S, Glander HJ, et al. Utility of magnetic cell separation as a molecular sperm preparation technique. J Androl. 2008; 29: 134-142.

PubMed: https://pubmed.ncbi.nlm.nih.gov/18077822/

41. Anslinger K, Bayer B, Danilov SM, Metzger R. Application of spermspecific antibodies for the separation of sperm from cell mixtures. Forensic Science International: Genetics Supplement Series. 2008; 1: 394-395.

42. Li XB, Wang QS, Yu Feng Y, Ning SH, Miao YY, et al. Magnetic beadbased separation of sperm from buccal epithelial cells using a monoclonal antibody against MOSPD3. Int J Legal Med 2014; 128: 905-911. PubMed: https://pubmed.ncbi.nlm.nih.gov/24590379/

43. $\mathrm{Xu} Y$, Xie J, Chen R, Cao $\mathrm{Y}$, Ping $\mathrm{Y}$, et al. Fluorescence- and magneticactivated cell sorting strategies to separate spermatozoa involving plural contributors from biological mixtures for human identification Sci Rep. 2016; 6: 36515.

PubMed: https://pubmed.ncbi.nlm.nih.gov/27857155/

44. Polzer B, Medoro G, Pasch S, Fontana F, Zorzino L, et al. Molecular profiling of single circulating tumor cells withdiagnostic intention. EMBO Mol Med. 2014; 30: 1371-1386.

PubMed: https://pubmed.ncbi.nlm.nih.gov/25358515/

45. Campton DE, Ramirez AB, Nordberg JJ, Drovetto NA, Clein C, et al. Highrecovery visual identification and singlecellretrieval of circulating tumor cells for genomic analysis using a dualtechnology platform integrated with automated immunofluorescence staining. BMC Cancer. 2015; 6: 360. PubMed: https://pubmed.ncbi.nlm.nih.gov/25944336/

46. Carpenter E, Rader J, Ruden J, Rappaport EF, Hunter KN, et al. Dielectrophoretic capture and genetic analysis of single neuroblastoma tumor cells. Front Oncol. 2014; 31: 201.

PubMed: https://pubmed.ncbi.nlm.nih.gov/25133137/

47. Espina V, Wulfkuhle JD, Calvert VS, VanMeter A, Zhou W, et al. Lasercapturemicrodissection. Nat Protoc 2006; 1: 586-603.

PubMed: https://pubmed.ncbi.nlm.nih.gov/17406286/

48. Kolble K. The LEICA microdissection system: design and applications.
J Mol Med. 2000; 78: 24-25.

PubMed: https://pubmed.ncbi.nlm.nih.gov/11043387/

49. MickeP,OstmanA,LundebergJ,PontenF.Laser-assistedcellmicrodissection using the PALM system. Methods MolBiol. 2005; 293: 151-166. PubMed: https://pubmed.ncbi.nlm.nih.gov/16028418/

50. Schutze K, Posl H, Lahr G. Laser micro manipulation systems as universal tools in cellular and molecular biology and in medicine. Cell MolBiol. 1998; 44: 735-746.

PubMed: https://pubmed.ncbi.nlm.nih.gov/9764744/

51. Emmert-Buck MR, Bonner RF, Smith PD. Laser capture microdissection. Science. 1996; 274: 998-1001.

PubMed: https://pubmed.ncbi.nlm.nih.gov/8875945/

52. Bonner RF, Emmert-Buck M, Cole K. Laser capture microdissection: molecular analysis of tissue. Science. 1997; 278: 1481-1483. PubMed: https://pubmed.ncbi.nlm.nih.gov/9411767/

53. Costa S, Correia-de-SP, Porto MJ, Cain L. The Use of Laser Microdissection in Forensic Sexual Assault Casework: Pros and Cons Compared to Standard Methods. J Forensic Sci. 2017; 62: 998-1006. PubMed: https://pubmed.ncbi.nlm.nih.gov/28133731/

54. Di Martino D, Giuffre G, Staiti N, Simone A, Todaro P, Saravo L. Laser microdissection and DNA typing of cells from singlehair follicles. Forensic Scilnt. 2004; 146: S155-157.

PubMed: https://pubmed.ncbi.nlm.nih.gov/15639565/

55. Anoruo B, van Oorschot R, Mitchell J, Howells D. Isolating cells from non-sperm cellular mixtures using the PALMmicrolaser micro dissection system. Forensic Sci Int. 2007; 173: 93-96.

PubMed: https://pubmed.ncbi.nlm.nih.gov/17459628/

56. Thorogate R, Moreira JC, Jickells S, Miele MM, Daniel B. A novel fluorescence-based method in forensic sciencefor the detection of blood in situ. Forensic Sci Int Genet. 2008; 2: 363-371.

PubMed: https://pubmed.ncbi.nlm.nih.gov/19083849/

57. Chalmers JJ, Zborowski M, Sun L, Moore L. Flow through, immunomagnetic cell separation. Biotechnol Prog. 199; 14: 141-148.

PubMed: https://pubmed.ncbi.nlm.nih.gov/9496679/

58. Jing $Y$, Moore LR, Schneider T, Williams PS, Chalmers JJ, et al. Negative selection of hematopoietic progenitor cells by continuous magnetophoresis. Exp Hematol. 2007; 35: 662-672.

PubMed: https://pubmed.ncbi.nlm.nih.gov/17379076/ 